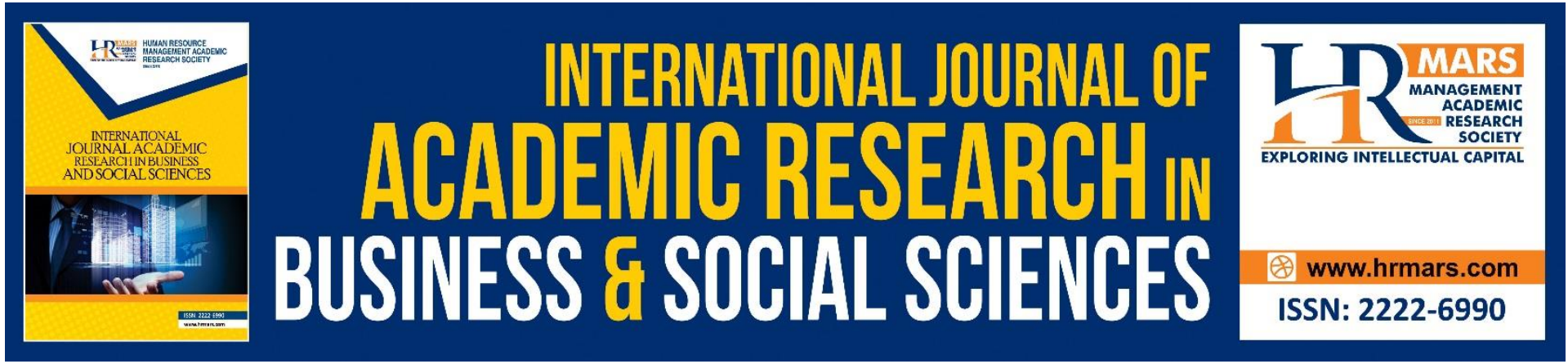

\title{
Development of Patriotism among Multiethnic Youths at Commemorative Heroic Site
}

Mohd Hasrul Yushairi Johari

To Link this Article: http://dx.doi.org/10.6007/IJARBSS/v11-i9/10763

DOI:10.6007/IJARBSS/v11-i9/10763

Received: 08 July 2021, Revised: 29 July 2021, Accepted: 21 August 2021

Published Online: 10 September 2021

In-Text Citation: (Johari, 2021)

To Cite this Article: Johari, M. H. Y. (2021). Development of Patriotism among Multiethnic Youths at Commemorative Heroic Site. International Journal of Academic Research in Business and Social Sciences, 11(9), 321-335.

Copyright: (c) 2021 The Author(s)

Published by Human Resource Management Academic Research Society (www.hrmars.com)

This article is published under the Creative Commons Attribution (CC BY 4.0) license. Anyone may reproduce, distribute, translate and create derivative works of this article (for both commercial and non-commercial purposes), subject to full attribution to the original publication and authors. The full terms of this license may be seen at: http://creativecommons.org/licences/by/4.0/legalcode

Vol. 11, No. 9, 2021, Pg. 321 - 335

http://hrmars.com/index.php/pages/detail/IJARBSS

JOURNAL HOMEPAGE

Full Terms \& Conditions of access and use can be found at http://hrmars.com/index.php/pages/detail/publication-ethics 


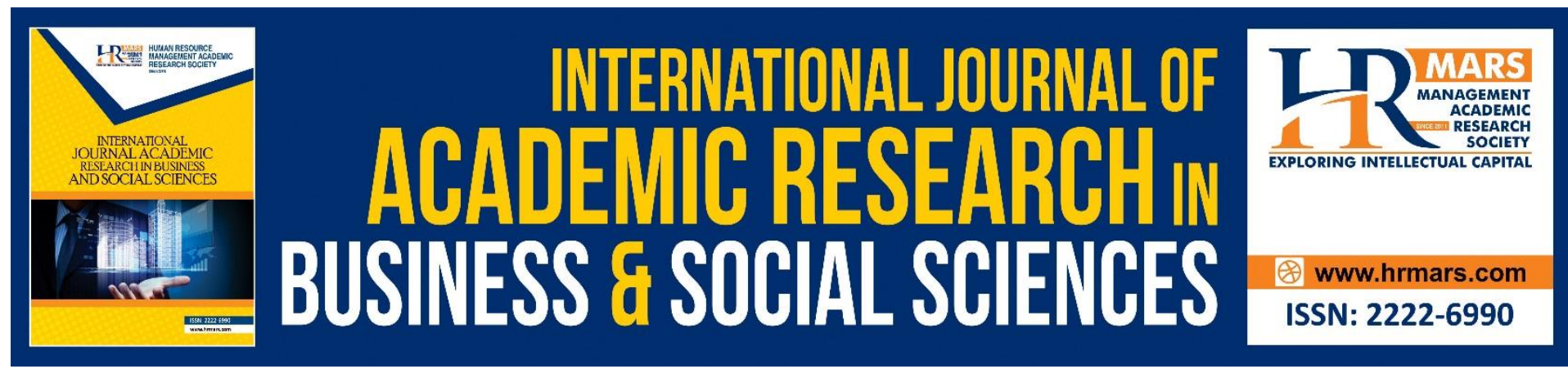

\title{
Development of Patriotism among Multiethnic Youths at Commemorative Heroic Site
}

\author{
Mohd Hasrul Yushairi Johari \\ Faculty Hotel \& Tourism Management, Universiti Teknologi MARA (UiTM) Kampus \\ Bandaraya Melaka \\ Email: hasrul436@uitm.edu.my
}

\begin{abstract}
The study is relevant to display a determination in showing commitment and enthusiasm to achieve unity goals in the country through ethnic heritage representation at a gallery. The spirit of patriotism needs to be inspired and motivated into the tourists especially among Malaysian youth since children. It was reported that majority of Malaysian youths scored a moderate level of patriotism with negative attitudes. This signified an alarming situation since youth is the future leaders. However, there are limited studies that examined the level of patriotism among Malaysian youth tourists at a commemorative historical site. It is still unclear how youth develop their patriotic spirit during a visit to a memorial historical site. This is because they never understood the colonial dominance that devastated many of our forefather's happiness. The study utilized quantitative approach by employing systematic random sampling using intercept technique that every fifth respondent who exit the historical complex was approached. Overall, only 252 respondents were used for the study, which recorded $72.8 \%$ responses from overall sample size. Results revealed that after visiting commemorative historic site, they identified that historical sites were important ( $\bar{x}=4.5794)$ that made them become a loyal citizen $(\bar{x}=4.7054)$ and appreciated the sacrifices made by the past warrior. Dimension of national pride, connection to countrymen and national belonging were all statistically significant at $P<.005$. Further research should be conducted at a more holistic level among multi-ethnic communities nationwide to identify their patriotism based on the shared cross-cultural immersion that have been long practiced in the country since independence.
\end{abstract}

Keywords: Patriotism, Historic Site, National Belonging, National Pride, Connection to Countrymen

\section{Introduction}

The spirit of patriotism needs to be inspired and motivated by the tourists especially among Malaysian youth since children. As a developing country, Malaysia's government needs to emphasize the spirit of patriotism to ensure that important histories are to be remembered and appreciated by local tourists. Malaysia is a country that has many historical places and stories that can be a place for education to gain knowledge and to know about the history of past patriots to increase patriotism in each individual. This can be done by enriching value 
with moral and ethical excellence in all aspects. When discussing patriotism, the importance of society, the process of forming a nation-state, the history and background of society should be taken into consideration. This is because the process takes a long period to create a generation that could be called a nation with a strong spirit of patriotism.

In Malaysia youth is in the age bracket between 15 and 30 as defined by Youth Societies and Youth Development Act (Amendment) 2019 (Act 668). The basic element that needs to be addressed to build a nation-state is developing patriotism among Malaysian youth. Patriotism is the spirit of desire to fight for the dignity of a nation. This spirit can be achieved when all Malaysians can appreciate the true meaning of independence. In appreciating this meaning, they should not just celebrate the sacrifice of the past patriots who risked their lives for independence but to acknowledge the value of their spirit which develops patriotism in the hearts of Malaysian.

\section{Background of Study}

Commemorative historical site is a location where pieces of political, military, or social history have been preserved due to their cultural heritage value. The site is usually protected by law and many have been recognized as the national historic site. According to Johnson (1995), such site represents a nation's past which is an important element in the construction of national identity. Tourism sites like a battlefield, monuments and museums may project a dominant discourse of patriotism. Pasir Salak Historical Complex (PSHC) was chosen as a field study because it is one of the largest historical complexes in Malaysia. PSHC pays tribute to warriors such as Dato' Sagor and Dato' Maharajalela who led the locals against the forces of the British colonials. The bloody tragedy of the assassination of James Wheeler Woodford (JWW) Birch, the first British Resident in Perak (1874-1875) on November 2, 1875 when Muslims welcomed the second Aidilfitri engraved the name of Pasir Salak in Malaysia history. The Birch massacre was the climax of the rise and resistance of the Malays towards the British occupation.

The implications of the Pasir Salak incident sparked the patriotic spirit that rose in 1946 against the Malayan Union and continued to blow the war of independence until the independence of the country on 31 August 1957. The complex portrays the history of Malaysian patriots in struggling for independence. The historical complex was constructed so that people could remember and honor their battle for the love of the motherland. This study investigated the memorial historical site in enriching patriotism among Malaysian youth tourists at PSHC, Perak. Hechter (2000) summarizes that patriotism is defined as the attempt to assimilate culturally distinctive territories in which heritage, is the focus of patriotism (Lowenthal, 1998). If one truly empathizes with such a battle of the past, PSHC awakens the slumber of Malaysian youth on a struggle of past warriors who fought for freedom and equal rights.

According to Shumway (1991), the creation of national identity is the people's attachment to the nation. It is necessary to develop individuals' sense of patriotism and collective identity. This research aims to investigate the elements of national pride, connection to countrymen, and national belonging among Malaysian youth who visit the commemorative historic site. Second, it examined the relationship between youth demographic profile and dimensions of patriotism. Understanding the level of patriotism embedded among Malaysians at a historical 
site is important since the results could help Tourism Malaysia to strategize some improvements at commemorative war historical areas to strengthen patriotism among Malaysians.

\section{Problem Statement}

For any country wishing to emerge as a strong and respected country, the spirit of patriotism must be an essential element in building and maintaining national sovereignty. But it is hard for us to be confident that Malaysians have a strong sense of patriotism. Abu Bakar (2017, p.80); Ismail et al (2017, p. 97) reported that most Malaysian youths scored a moderate level of patriotism. Besides, Bandu et al (2015) claimed that younger generations are low in the patriotic spirit with negative attitudes who are more individualistic. Mohamed et al. (2011, p. 4293) are also in the same opinion that youths are lacking their nationalism spirit. This signified an alarming situation since youth is the future leaders. However, there are limited studies that examined the level of patriotism among Malaysian youth tourists at a commemorative historical site. It is still unclear how youth develop their patriotic spirit during a visit to a memorial historical site. This is because they never understood the colonial dominance that devastated many of our forefather's happiness. Hamzah \& Suandi (1996) and Dahalan et al. (2011) argue that the nature of patriotism among youth today has not much changed since the 1970s, that they have failed to understand and appreciate the spirit of love for their homeland. Similarly, Omar (2002) states that youth are directionless in seeking patriotic spirit in defense of national sovereignty. In general, when tourists visit the war memorial historical site, they took pictures and read the information panel but their appreciations of the independence struggles are not deep (Abu Bakar, 2017). It is because such things are not close to them that they have not witnessed historical events by themselves (Mohamed et al., 2011). Supposedly, for the youth to restore the lack of patriotism within themselves, they must appreciate the sacrifices made by the national heroes who fought for the country's independence. Therefore, based on the abovementioned problems, two research questions guided the study, i.e. first, how the commemorative historic site can help enrich patriotism among Malaysian youth? and second, what are the elements that inculcate patriotism at the memorial historic site?

\section{Patriotism and Historic Site}

Patriotism is a term that represents feelings of pride and dignity. The term "patriotism" is generally used to describe two phenomena, i.e. firstly, the attitude that the members of a nation have when they care about their national identity, and secondly, the actions that the members of a nation take when seeking to achieve self-determination. In general terms, national identity is very subjective with complex representations of feelings and characters related to a group of people (Omelchenko et al. 2015), while Huddy \& Khatib (2007) define national identity as a sense of belonging to the nation. Following Huddy \& Khatib's (2007) work, national identity is expected to be non-ideological because it represents a sense of attachment to the nation and a strong national identity needs to have a continuous effort from the government.

The degree of care for one's nation is a pure reaction when talking about a country. This is because of their love and loyalty towards their nation. It happens because they feel that their country is the best than in other countries. Patriotism involves a deep feeling that someone feels regarding his country (Abu Bakar, 2017; Dahalan et al., 2011; Bandu et al., 2015; 
Mohamed et al., 2011). However, such feelings are not auto-generated, i.e. one needs to be exposed and taught some knowledge about the country itself. Qian, Xu \& Chen (2016) believe that without teaching and learning process, patriotic education will be imperfect; hence the level of patriotic spirit would become shallow. The youth needs to feel proud of our national patriot for being so brave and bold in defending our country, involving in a bloody fight just to make sure the later generation will not suffer just like they did. Therefore, patriotic spirit demands some continuous commitment since patriotism involves critical loyalty towards the nation (Latcheva, 2010).

Patriotism also means having and maintaining high respect for the laws, policies, and principles of the country. The community needs to have a strong base of nationhood so that they can lead their country to be better. This will entail spreading the spirit of patriotism to other individuals irrespective of the country they belong to. The freedom that we have today is not gained by coincidence. There is an emotional journey with blood and tears to obtain the independence that we celebrate every year. Our patriots gave their very best to make sure that we do not lose our motherland to the hand of the colonials. This further implies that a patriot will always place his nation first before any other country or individual. The more one inculcates love and obedience to a country, the more sensitive one is to the potential threats to the country. In other words, their attachment to the country evokes emotions that lead to actions that uphold the sovereignty of the nation. Such an act of national pride is so obvious and deemed important for the young generation to understand. For Evans \& Kelly (2002, p. 305), it makes sense to investigate views of national pride in a nation and feelings of closeness to one's country. It is because the loss of faith in achievement of the past, disunity, moral decadence, and decline in intellectual can be factored in the decline of a culture or civilization (Ashimi, 2016, p. 183).

Whittaker (2019) recognizes that there is a need to explore the spirit of nationalism within each ethnicity and religious affiliation to establish a national identity. Lambeth (2010) further explains that the government desires to rationalize living together and to cherish each other's heritage, thus creating a national sense of belonging. In this regard, Higgins (2018) expresses his concern through post-colonial melancholia and the nostalgia of the past on how tensions during colonialism were acceptable to the public. Yeoh, Acedera \& Rootham (2019) explain that nationalist thinking can be complex especially for the Malays, Chinese, and Indians unless they all negotiate to understand the context of unity in a country. Gabriel (2011) participates in this view on the spirit of unity through the concept of Bangsa Malaysia, which promotes national belonging that replaces the National Cultural Policy that places greater emphasis on Malay privileges. In this case, Howes (2016) argues that every ethnic identity needs to uphold the spirit of national belonging to create a proud citizenry and love of the nation.

Although there are not many studies that investigate the connection between how patriotism is formulated at commemorative historical sites, several authors have worked on similar historical-theme sites that examined the patriotic level of the respondents. Weaver et al. (2018) in a survey of 1,082 domestic visitors to Lushun Prison Museum in Dalian, China, claimed that most respondents registered strong emotional reactions and elevated patriotism along with the madden feelings toward Japan, Japanese products and Japanese people, as a result of the tense China-Japan bilateral relationship. Some, like Tej and Matusikova (2015) highlight that cultural heritage carnival, birthplace monuments, and historic childhood homes 
contribute to boosting awareness of the patriotism of the locals. All of these authors' arguments lead to a perception that patriotism exists based on the reliance on a society that values the historical significance of homeland (Smith, 2001). Emphasizing the importance of preserving the country's historical treasures includes a deep interest in the study of history, preserving the mother tongue language including the philological and lexicographic, and traditional art restoration of the local people such as native song and music (Lambeth, 2010).

Studying history will make people aware of their roots and origin. At the same time, they also seek lessons from past stories to improve their condition wellbeing. By learning about the causes and effects of history, one can learn more effective ways of dealing with conflicts in society. This method not only enhances one's awareness but also instills deeper love in one's life. Historic sites are an ideal place to assess one's level of love for the country. Historic sites such as old buildings, landscapes, or ruins of old structures create an atmosphere that allows one to reflect on the past and understand the events that happened in ancient history.

\section{Study Framework}

The study adopted the work of Bogdanov (2005) to measure the patriotism level among participants. Bogdanov (2005) in his sports study has developed items to measure three dimensions believed to generate patriotism, i.e. national belonging, connection to countrymen, and national pride.

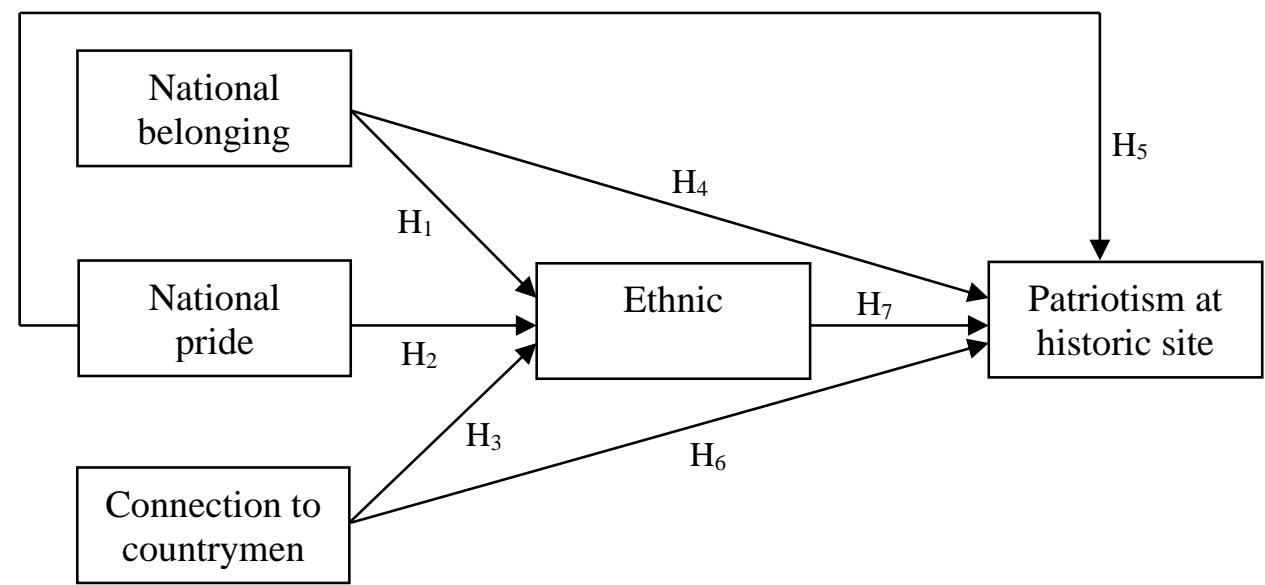

Figure 1.0: Research framework (Source: Modified from Bogdanov, 2005)

The criterion variable of this study is patriotism at a historical site. Qian, Xu and Chen (2016) contend that the meaning of patriotism is always overlapping with the term nationalism but regardless of its small significant differences, its aim is always the same, i.e., support for the home country. Examining from different perspectives, patriotism at historic sites could be determined by some elements determined by several predictors, i.e., national pride, national belonging, and connection with countrymen. Though the above patriotism dimensions were established based on Bogdanov's (2015) work on the effect of nationalism in a sporting event, the patriotism framework of the present study was established based on fragmented discussions of many authors since there are no single studies that utilize the three dimensions in measuring patriotism of youth tourists at a historic site. If one accepts the assumption that national pride is indeed instilling patriotic sentiments, one should expect that visiting the historical site will reinforce patriotism (Weaver, et al., 2008; Tej \& Matusikova, 2015; 
Bruggemean, 2012). It is expected that a tourist to the commemorative historic site should expect that his national pride is likely to grow (Lambeth, 2010; Smith, 2001). It is also relevant that his ties with countrymen will be strengthened (Gabriel, 2011) and his national belonging resulting from learning the historical moments would enhance (Yeoh, Acedera \& Rootham, 2019). Therefore, this study attempted to hypothesize that:

$\mathrm{H}_{1}$ : There is significant difference between national belonging and type of ethnic

$\mathrm{H}_{2}$ : National pride is positively related with ethnic

$\mathrm{H}_{3}$ : Connection to countrymen has a significant association with ethnic

$\mathrm{H}_{4}$ : Patriotism at historic site is greatly influenced by the national belonging

$\mathrm{H}_{5}$ : National pride has a strong positive relationship with patriotism at historic site

$\mathrm{H}_{6}$ : There is positive association between connection to countrymen and patriotism at historic site

$\mathrm{H}_{7}$ : Different types of ethnics has different levels of patriotism at historic site.

\section{Methodology}

From the record of tourist arrival, PSHC received an average of 3,514 total annual visitors (Lembaga Muzium Negeri Perak, 2017). Based on Krejcie \& Morgan's (1970, p. 608) table of sample size, about 346 samples were derived for the study. The study employed systematic random sampling. Intercept technique was utilized that every fifth respondent who exits the historical complex were approached. Overall, only data of 252 respondents were utilized for the study, which recorded $72.8 \%$ responses from the overall sample size due to lack of commitment from potential respondents. The survey form was distributed to youth respondents only over a week between 9 am and $5 \mathrm{pm}$.

The questionnaire had undergone filter technique to check the youth age bracket between 18 and 30 years old. Any respondents outside the age parameter were removed as sample. Permission from the museum personnel was obtained for the field survey. Target respondents were the local tourists since Malaysian patriotic spirit was the study objective. All survey forms were completed at the exit of the museum so that tourists had ample time for a full complete tour experience in the complex. Tourists were asked their willingness to participate in the survey. They were asked to proceed with answering the questionnaire should they agreed.

There were three sections which consist of Section A on demographic profile comprising gender, age, level of education, occupation, information source, travel frequency, and travel companion. Section B covered 6 travel behavior questions with a dichotomous response of yes or no. The questions were to reveal tourist opinion on the visit frequency, earlier knowledge of the complex, motivation to visit the historical site, accessibility to location, availability of facilities, and information board.

Section C comprised 8 questions for national pride (historical site visit, sense of pride, enhance patriotism through symbol, appreciation of sacrifices, proud as Malaysian, strong national identity, increase knowledge on warrior and historical site develop patriotism), 6 items for connection with countryman (talks about history with other countrymen gives a feeling of unity, historical event gives sense of connection with fellow countrymen, talking about historical event with my countrymen gives me a sense of solidarity, feel proud of the country, 
my nation as the core of my identity and I am a loyal citizen of my country) and lastly 8 statements on national belonging that inquired on sense of national belonging to historical site, historical reading provide sense of national belonging, proud of country's history, creation of sense of belonging when sharing stories, reinforcement of national identity through site visit, feel a strong sense of belonging to the country, increase knowledge and historical site help improve patriotism.

All the items were measured based on a 5-point Likert scale ranging from 1, strongly disagree to 5, strongly agree. A pilot study of the instrument registered .82 Cronbach Alpha which signified a good reliable instrument. Any wordy and confusing statements were corrected accordingly to produce a clear questionnaire. The data were analyzed using SPSS (Statistical Package for Social Sciences). Descriptive and Pearson correlation were conducted to reveal important information about the study.

\section{Results and Discussion}

For the demographic profile, most of the tourists were male $(42.7 \% \%)$ and female $(32 \%)$. Most of them (100.00\%) were youth between 18 and 30 years old with the majority of them (53\%) with first and postgraduate degrees. In terms of ethnicity, Malay registered $82.5 \%$, Chinese $10.7 \%$, and Indian $6.7 \%$. Majority of them were students (39.5\%), with career $(37.9 \%), 4.7 \%$ of them were unemployed and only $2.7 \%$ claimed that they were a retiree. Many of them were first timer (73\%) who were accompanied by their spouse, family, and friends (86.6\%). Many of them obtained information about the place through advertisements (77.4\%) including social media, the internet and any other forms of promotion. In terms of respondent travel behaviour, this study indicated that most of the visitors (67.9\%) have heard about PSHC and only $32.1 \%$ never heard about the complex. Many respondents (94.6\%) were motivated to visit the complex and agreed that the site was easily accessible (90.2\%). Many provided feedback that the complex provides good facilities (89.3\%) especially the display boards were complete with information (92.9\%).

Table 1.0

Respondents' feedback on level of patriotism

\begin{tabular}{lllllllll}
\hline No Patriotism dimension & 1 & 2 & 3 & 4 & 5 & Mean Std. Dev $\begin{array}{l}\text { Ran } \\
k\end{array}$ \\
\hline
\end{tabular}

National Pride

1. Visiting historical site makes me proud of my country. $0 \quad \begin{array}{lllll}0 & 17 & 1241024.265 & 0.7390 & 6\end{array}$

2. Reading about historical information gives me sense ofo $\quad 0 \quad 3813381 \quad 4.1700 .6669 \quad 7$ pride with my country.

3. Every time I see patriotic symbol it will enhance0 $252999994.0790 .9497 \quad 8$ patriotism in myself.

4. I appreciate the sacrifices made by the national patriot $0 \quad 0 \quad 1086 \quad 1564.5790 .5697 \quad 1$ for the sake of our country's independence.

5. I am proud to be Malaysian.

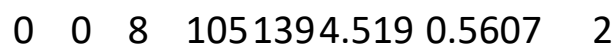

8

6. Historical events contribute to a stronger national1 $7 \quad 131111204.3570 .7411 \quad 3$ identity. 
7. Visiting historical site increase my knowledge about0 $3 \quad 19 \begin{array}{llll}1261044.313 & 0.6647 & 4\end{array}$ national fighter.

8. Overall, historical site has helped to develop patriotismo $\quad 1 \quad 23 \quad 1271004.3010 .6470 \quad 5$ in me.

\section{Connection with Countrymen}

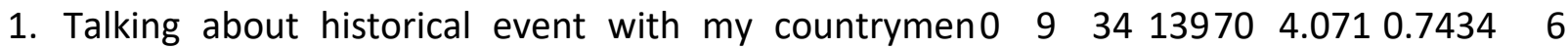
gives me the feeling of unity.

2. Historical event gives me sense of connection with my0 $0 \quad 26148784.2060 .6096 \quad 5$ fellow countrymen.

3. Talking about historical event with my countrymeno $\quad 0 \quad 141121264.4440 .5995 \quad 3$ gives me a sense of solidarity.

4. I went to historical site, and I feel proud of my country. 010341001084.2140 .8240

5. My nation is at the core of my identity.

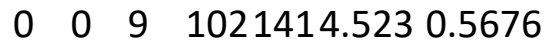

8

6. I am a loyal citizen of my country regardless in what0 $72514674 \quad 4.7050 .51357 \quad 1$ situation.

\section{National belonging}

1. Visiting historical site provides sense of national10 1232100984.0471 .03227 belonging to my nation

2. Reading about my country's historical event provides4 $283610183 \quad 3.9161 .0280 \quad 8$ sense of national belongings to my nation

3. I am proud of my country's history

4. Talking about my country to others increase sense of $0 \quad 0 \quad 271201054.3090 .6555 \quad 3$ belonging to my nation

5. Visiting historical site reinforces my national identity

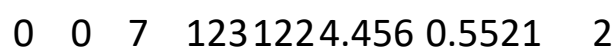

6. I have a strong sense of belonging to my country

$4 \quad 3 \quad 341051064.2140 .8384 \quad 6$

7. Historical sites are important to me

8. I am Malaysian and proud to have citizen of Malaysia

$\begin{array}{lllllll}0 & 0 & 6 & 97 & 1494.567 & 0.5424 & 1\end{array}$ 5

Table 1.0 shows the results of respondent feedback on national pride, connection with countrymen and national belonging. For national pride, appreciation of the sacrifices made by the national patriot was ranked the highest ( $\bar{x}=4.5794)$, followed by proud to be Malaysian) which ranked second. About $92 \%$ of respondents agreed that historical event contributes to a stronger national identity (Ranked third). Even though the patriotic symbol was ranked the last, the results revealed that $78.5 \%$ of youth agreed that patriotic symbol enhanced their level of patriotism. For connection with countrymen, most of the respondents confirmed that they would always be loyal citizens regardless in whatever situation ( $\bar{x}=4.7054$, Rank 1$)$ since the thought that their nation is the core of identity $(\bar{x}=4.5238$, Rank 2$)$. They also agreed to talk to other countrymen by sharing stories about historical events to provide some sense of solidarity ( $\bar{x}=4.4444$, Rank 3 ). In terms of national belonging, many youths identified that historical sites are important ( $\bar{x}=4.5675$, Rank 1$)$ because it reinforced their national identity 
$(\bar{x}=4.4563$, Rank 2$)$. Approximately $89.2 \%$ of them agreed that talking about their country to others might increase their sense of belonging to the country $(\bar{x}=4.3095$, Rank 3$)$.

a) Hypotheses Testing

Table 2.0

Dimensions of patriotism with ethnicity and patriotism at historical site

\begin{tabular}{|c|c|c|c|c|}
\hline \multicolumn{5}{|l|}{ Correlations } \\
\hline & & & Ethnic & $\begin{array}{l}\text { Patriotism at historical } \\
\text { site }\end{array}$ \\
\hline \multirow{3}{*}{\multicolumn{2}{|c|}{ National belonging }} & Pearson Correlation & -.107 & $.351^{* *}$ \\
\hline & & Sig. (2-tailed) & .090 & .000 \\
\hline & & $\mathrm{N}$ & 252 & 252 \\
\hline \multirow{3}{*}{\multicolumn{2}{|c|}{ National pride }} & Pearson Correlation & $-.152^{*}$ & $.351^{* *}$ \\
\hline & & Sig. (2-tailed) & .016 & .000 \\
\hline & & $\mathrm{N}$ & 252 & 252 \\
\hline \multirow{3}{*}{$\begin{array}{l}\text { Connection } \\
\text { countrymen }\end{array}$} & to & Pearson Correlation & $-.185^{* *}$ & $.381^{* *}$ \\
\hline & & Sig. (2-tailed) & .003 & .000 \\
\hline & & $\mathrm{N}$ & 252 & 252 \\
\hline
\end{tabular}

**Correlation is significant at the 0.01 level (2-tailed)

* Correlation is significant at the 0.05 level (2-tailed)

Table 2.0 depicts the findings of hypotheses 1-6. The data revealed that for ethnic, the dimension of national pride and connection to countrymen were registered significant at $\mathrm{P}<0.05$ and $\mathrm{P}<0.01$ respectively. However, national belonging was found insignificant, with score 0.09 . Therefore, $\mathrm{H} 1$ was rejected. Nonetheless, $\mathrm{H} 2$ and $\mathrm{H} 3$ were accepted. For $\mathrm{H} 1$, the data signified that Malays, Chinese and Indians showed no difference in their love for the homeland. All of them were of the view that it was their responsibility regardless of racial background to jointly maintain the country's sovereignty. According to them, their love for the homeland grew stronger through their interactions with other ethnic, thus making them proud of their homeland's history. Although there are studies that show racial sentiment is obvious in Malaysia in terms of history, education, social, political and economic (Abdullah, 2010, p. 62; Hamedan et al., 2019, p. 303), yet in terms of appreciation of history, it seems that every ethnic group is able to understand the hardships of former warriors defending their homeland. This is likely because $73 \%$ of youth from each ethnic group read a lot about history; possibly due to exposure to the historical subjects they learned while in school (see Table 1.0). This finding is in line with the views of Ahmad \& Hamid (2015) who argue that environmental influences are closely related to civilization, history, and the spirit of unity which act as elements that lead to high morale. Idris et al. (2019, p.40) were very firm that every youth should instill a love for the country and their countrymen so that racial or religious sentiment will be reduced and replaced by a spirit of patriotism.

In addition, national belonging, pride and connection to countrymen were also tested against youth responses on historical site that has helped develop their patriotism. As revealed in the above table, all hypothesis 4,5 and 6 were accepted at $P<0.01$. These findings prove that the spirit of patriotism exists around humanity and that it remains relevant today (Amir Hamzah, 2019, p. 95). Hamdan (2019, p. 38) expresses this as a love of history and culture 
that is passed down from generation to generation which highlights the warrior figure as a hero. The understanding of patriotism is built on accurate historical facts. This is in line with the element of historical truth that it plays an important role in fostering patriotism (Suminar, Wasino \& Handoyo, 2019). Learning about history becomes more meaningful as it shifts from memorizing historical facts to experiential historical learning especially during visits to historic sites. Suminar, Wasino \& Handoyo (2019) explain that historical literacy has the potential to foster someone's understanding of history. However, Hawkman \& Van Horn (2019) warn that one must be careful about the tendency of becoming 'blind' patriotic practices who is pretending to be loyal and someone who has no principle but to follow others without knowing the purpose. In view of this, Hawkman \& Van Horn $(2019$, p. 119) emphasize that patriotism needs deep understanding and every citizen must involve in community activities to foster a stronger sense of belonging. The data also revealed that almost $84 \%$ youth were in their opinion that they had a strong sense of belonging to Malaysia and they were very proud to be Malaysian (97\%) (see Table 1.0).

Table 3.0

Relationship between patriotism at historical site and ethnic

\begin{tabular}{lll}
\hline \multicolumn{2}{l}{ Correlations } & \\
& & Ethnic \\
\hline Historical site has Pearson & -.113 \\
helped to develop Correlation & \\
patriotism in me & Sig. (2-tailed) & .073 \\
& $\mathrm{~N}$ & 252 \\
\hline
\end{tabular}

Finding for Hypothesis 7 exposed insignificant association between historical site and type of ethnic background. Hence, the hypothesis was rejected. This implied that Malay, Chinese, and Indians were not in the same opinion on what they learned at the commemorative heroic site to improve their level of patriotism. Even though their historical literacy was satisfactory, but their level of emotional attachment to history was not deep, thus hampered their immersion to get into knowing the real hero which was represented in monotonous gallery exhibits. Perhaps, some dioramas and videos with sounds of terror and dramatic fighting in a spacious theatre room would fascinate these youth to become more interested to understand history, thus increase their love for the country. Since the exhibits undeniably emphasize the contribution of Malay warriors, Chinese and Indian youth found that it was not connected to their identity roots. The findings in Table 1.0 revealed that nearly a quarter of youths $(21.4 \%)$ disagreed and were undecided that their patriotism will enhance every time they see the patriotic symbol. They also argued that visiting historical site did not provide them a sense of belonging to the nation. More than a quarter of them (27\%) replied that they still did not develop national belonging even after reading historical events in the historical complex. Since the interpretation in the PSHC was one-sided of Malay historical story, therefore the Chinese and Indian youth felt that they were left out in the Malaysian historical representation. Therefore, the interpretation in the historical complex needs to consider any historical shreds of evidence on other ethnic contributions towards independence or any incidents of Chinese and Indians records on fighting the colonials. Such social inclusion is important for strengthening the historical understanding that could lead to an increased level of patriotism. In this sense, Black (2019) argues that the practice of social inclusion enables one to avoid a feeling of unjust or oppression. He noted that it is important to practice 
inclusion because it provides them the feeling of appreciation, shows respect, and makes them feel welcome. Pidgeon $(2015$, p. 80$)$ stresses that this approach should be practiced at all levels that include all groups of people, regardless of race and gender.

\section{Implications and Contributions of the Study}

The current generation, especially the young generation of Malaysia will determine the future of the country. Therefore, it is appropriate for the government to continue and strengthen the importance of the historic sites to improve the delivery of information and national education for the wellbeing and future development of nationalism among Malaysians. Malaysian youth should be involved with the government's desire to build a viable, highly patriotic, and nationalist-minded to understand the values of nationalism. Malaysia's new generation should consist of people with a high appreciation for talent, dedication, and independence as well as a strong passion for national sovereignty. The advancement of multiple languages interpretation technology must be implemented to ensure that different ethnicities understand the real historical context and struggles of the past heroes in defending the country. The appreciation of nationalism will produce an identity that is enthusiastic, independent, intelligent, capable, and highly confident youths who could contribute to the development of the nation. Governments must use all their strength, critical thinking, creativity, and ability to educate them about nationalism successfully. The quality and professionalism of education should be developed in a centralized ethical culture surrounded by an excellent knowledge society. All organizations must work with the government administration to look into this matter seriously. The study contributes to some evidence of social integration concept and strengthening the National Unity Action Plan (Blueprint) 20212030 which was launched by Malaysia's Prime Minister Muhyiddin Yassin in February 2021 that promote integration through social, cultural, and sporting activities. The current study has therefore elevated the implementation of the spirit of unity among Malaysians which is based on the Constitution of Malaysia and social justice.

\section{Conclusion}

Cultivating patriotic spirit among youth requires consistent planning to ensure that the spirit is always instilled because of the ever-changing ways and lifestyles of today. Independence appreciation programs need to be implemented in maintaining and developing a generation that can withstand all kinds of challenges in their lives. Respect for patriotism will create strong characters among youth who loves the country, are capable, credible, and confident. Thus, they can contribute significantly to the national development and social welfare of the community. This is important because the country's future lies in the hands of Malaysian youth today. The government must use all its strength in generating critical thinking, creativity, and capability to successfully educate youth on patriotism. The quality of education should be developed so that youth become more knowledgeable about the struggle for independence. Therefore, educators and all organizations should work closely with the government to seriously consider this matter to produce more patriotic Malaysians. The improvement strategy should focus on all ethnic groups regardless of religion and race in Malaysia. In line with this effort, a community that understands the principles of the country can contribute to the development of the country by continuing to support the aspirations of unity for the sake of the beloved homeland. 
According to Hamid et al. (2013), despite the assimilation and integration of ethnicities in Malaysia, ethnocentrism led certain people difficult to adapt themselves to other societies of different ethnicities. This triggers differences and conflicts of values, beliefs, and cultures, e.g., there are still many Chinese who do not know and understand the values, culture, and belief system of the Malays and vice versa. This superficial understanding and knowledge of values, cultures, and belief systems have created stereotypes among them. Nevertheless, Embong (2000) is more optimistic by stating that although people of various races in Malaysia have diverse cultural backgrounds, they can form a new nation since they have been experiencing living together for a relatively long time and form national feelings. Although the history of the various races in the country is different, different ethnicities in Malaysia are increasingly accepting the fact that they share the same territory, economy, and the future and have a common Malay language. Yet, this opinion is only as appealing to oneself when Lee (2000) reported that after independence, ethnic relations became tangled and influenced by the struggles of competing ethnic communities for national identity, political power-sharing, and economic wealth distribution. Even so, Noor (2009) slammed the view because she argued that if a country wants to take steps towards progress, then the unfair stances and differences between ethnic groups need to be resolved. Since political leaders cannot be expected to do this task, the responsibility lies within the people themselves. If each ethnic group could put aside their interests and change their way of thinking, they would probably realize that their worries about other ethnicities were speculative. Thus, the effort opens opportunities to reduce the differences that have separated them over the years. She suggested that a psychocultural approach in the favour of peace of multi-ethnic relations based on cultural values should be shared. Understanding these shared values would not change the course of history but it could make a meaningful contribution to reducing inter-ethnic conflict thus paving the way for the groups to unite. Although the inter-ethnic conflict could not be completely ended, at the very least, the cultural similarities identified could engender feelings of consideration, sympathy, and mutual appreciation among multi-ethnic societies in Malaysia. All forms of racial or religious differences must be abolished. Harmony cooperation is a formula for success in the context of a mixed society in Malaysia. It is hoped that with all these strategies, Malaysia will continue to be a sovereign nation.

\section{Conflict of Interest}

The author hereby declares that there is no conflict of interest.

\section{Funding}

The author received no financial support for the research, authorship, and/or publication of this article.

\section{References}

Abu Bakar, S. (2017). Personaliti belia Malaysia masa kini. Malaysian Journal of Youth Studies, $16,71-86$.

Abdullah, M. R. T. (2010). Cabaran integrasi antara kaum di Malaysia: Perspektif sejarah, keluarga dan pendidikan. Jurnal Hadhari, 3, 61-84.

Ahmad, H., \& Hamid, H. A. (2015). Pengurusan pembangunan konsep perpaduan dalam kalangan pelajar sekolah menengah kebangsaan: Satu kajian di Klang, Selangor. Jurnal Kepimpinan Pendidikan, 2 (4), 1-15. 
Amadeo, K. (2019). Nationalism, what it means and its history: Comparing nationalism and patriotism. Retrieved from https://www.thebalance.com/nationalism-definitionexamples-pros-cons-41495 24.

Hamzah, A. S. (2019). A Malaysian nation brand: The dissemination of it by radio Malaya via the song tanah pusaka. Jurnal Komunikasi: Malaysian Journal of Communication, 35 (1), 90-102.

Ashimi, T. A. (2016). Islamic civilization: Factors behind its glory and decline. International Journal of Business, Economics and Law, 9(5), 180-184.

Bandu, S. H., Ahmad, A. R., \& Awang, M. M. (2015). Patriotism: Issue and challenges in Malaysia. In International Conference on Current Issues in Education (pp. 116-120). Yogyakarta: Yogyakarta State University.

Black, S. (2019). Diversity and inclusion: How to avoid bias and social media blunders. In Joe, J., \& Knight, E. (Eds.), Social Media for Communication and Instruction in Academic Libraries (pp. 100-118). Hershey, PA: IGI Global. doi: 10.4018/978-1-5225-80973.ch007.

Bogdanov, D. (2005). Measuring nationalism as a sport fan motive (Master's thesis). Florida State University Libraries. Retrieved from https://fsu.digital.flvc.org

Dahalan, D., Ahmad, N., Hassan, M. S., Muda, M., Othman, J., \& Abdullah, N. A. W. (2011). The challenges of 1Malaysia and the reality of youth's involvement with the unity campaign on television. Australian Journal of Basic and Applied Sciences, 5, 21322138.

Embong, A. R. (2010). Malaysian studies: Looking back, moving forward. Kajang, Selangor: Persatuan Sains Sosial Malaysia.

Evans, M. D. R., \& Kelly, J. (2002). National pride in the developed world: Survey data from 24 nations. International Journal of Public Opinions, 14(3), 303-338.

Gabriel, S. P. (2011). Translating bangsa Malaysia: Toward a new cultural politics of Malaysian-ness. Critical Asian Studies, 43(3), 349-372.

Idris, F., Muda, K., \& Mastor, K. A. (2019). Pembentukan model toleransi beragama belia pelbagai etnik di Malaysia. Akademika, 89 (2), 33-42.

Ismail, H., Syed Hussain, T. P. R., Nasarah, S. A., Mohd Yusof, W., \& Othman, Z. (2017). Nilai patriotisme belia Malaysia. Malaysian Journal of Youth Studies, 16, 87-100.

Hamdan, R. (2019). Wira Melayu menurut persepsi pelajar. Jurnal Kesidang, 3, 33-39.

Hamid, M. A. A., Yusoff, M. R., Othman, M. F., \& Balwi, M. K. (2013). Perspektif orang Cina terhadap agama Islam di Malaysia: Satu tinjauan. Jurnal Teknologi, 60, 11-19.

Hamedan, N. N., Alsagoff, S. A. S., Ghazali, A. H. (2019). Media, isu dan tingkah laku pengundi dalam pilihan raya umum ke-14: Satu kajian awal. Jurnal Komunikasi: Malaysian Journal of Communication, 35 (2), 293-312.

Hamzah, A., \& Suandi, T. (1996). Isu dan cabaran dalam pembangunan belia: Beberapa pemerhatian penting. Kertas kerja Persidangan Majlis Perundingan Belia Negeri Sembilan. Seremban.

Hechter, M. (2000). Containing patriotism. Oxford: Oxford University Press.

Higgins, K. W. (2018). Tense and the other: Temporality and urban multiculture in Auckland, Aotearoa New Zealand. Transactions of the Institute of British Geographers, 44(1), pp. 168-180.

Howes, L., Hammett, D. (2016). Negotiating identities and emotional belonging: Shan in northern Thailand. Emotion, Space and Society, 19, 21-28. 
Huddy, L., \& Khatib, N. (2007). American patriotism, national identity, and political involvement. American Journal of Political Science, 51 (1), 63-77.

Hawkman, A. M., \& Van Horn, S. E. (2019). What does it mean to be patriotic? Policing patriotism in sports and social studies education, The Social Studies, 110 (3), 105-121.

Johnson, N. (1995). Cast in stone: Monuments, geography and patriotism. Environment and Planning D: Society and Space, 13, 51-65.

Krejcie, R. V., \& Morgan, D. W. (1970). Determining sample size for research activities. Educational and Psychological Measurement, 30, 607-610.

Lambeth, L. (2010) Nationalism, Nationhood and Identity in Virtual Worlds and MMORPG's. POLIS Journal, 3, 1-35.

Latcheva, R. (2010). Nationalism versus Patriotism, or the Floating Border? National Identification and Ethnic Exclusion in Post-communist Bulgaria. Journal of Comparative Research in Anthropology and Sociology, 1, 187-216.

Lembaga Muzium Negeri Perak. (2017). Statistic of Pasir Salak Historical Complex.

Lee, H. G. (2000). Ethnic relations in Peninsular Malaysia: The cultural and economic dimensions. Social and Cultural Issues, 1, 1-45.

Lowenthal, D. (1998). The heritage crusade and the spoils of history. Cambridge: Cambridge University Press.

Mohamed, A. S. P., Sulaiman, S. F., Othman, M. F., Yang, M. A. C. J., \& Haron, H. (2011). Patriotism dilemma among Malaysian youth: Between strategy and reality. Elixir Social Science, 38, 4293-4298.

Noor, N. M. (2009). The future of Malay-Chinese relations in Malaysia. In C. J. Montiel and N. M. Noor (Eds.), Peace Psychology in Asia (pp. 161-172). New York, NY: Springer US. doi:10.1007/978-1-4419-0143-9

Omar, A. (2002). Dasar bahasa dan budaya Malaysia tidak konsisten. Berita Harian, 22 Ogos.

Omelchenko, D., Maximova, S., Noyanzina, O., Goncharova, N., \& Avdeeva, G. (2015). National identity and patriotism among Russian youth: Representations, feelings and actions. Asian Social Science, 11, 27-36.

Pidgeon, M. (2015). More than a checklist: Meaningful indigenous inclusion in higher education. Social Inclusion, 4 (1), 77-91. doi: 10.17645/si.v4i1.436.

Qian, L., Xu, B., \& Chen, D. (2016) Does History Education Promote Nationalism in China? A 'Limited Effect' Explanation. Journal of Contemporary China, 26(104), 199-212.

Shumway, N. (1991). The invention of argentina. University of California Press, Berkeley, CA. Smith, A.D. (2001). Nationalism: Theory, ideology, history. Cambridge: Polity.

Suminar, R., Wasino \& Handoyo, E. (2019). The utilization of Hindhu Buddhist heritage sites to develop the student's historical literacy of public senior high school 1 Boja. Journal of Educational Social Studies, 8 (1), $92-100$.

Tej, J., \& Matusikova, D. (2015). Carnival as a tourist product and its place in the local development. Economic Annals-XXI, 155(11-12), 114-116.

Weaver, D., Tang, C., Shi, F., Huang, M., Burns, K., \& Sheng, A. (2018). Dark tourism, emotions, and postexperience visitor effects in a sensitive geopolitical context: A Chinese case study. Journal of Travel Research, 57(6), 824-838. doi:10.1177/0047287517720119

Whittaker, G. R. (2019). When I'm there I get a sense of who I'm not: The impact of family visits on the national place-belongingness of Welsh Muslims. Political Geography, 74, doi:10.1016/j.polgeo .2019.102037

Yeoh, B. S. A., Acedera, K., Rootham, E. (2019). Negotiating postcolonial Eurasian identities and national belonging in global-city Singapore. Social Identities, 25(3), 294-309. 